\section{Influence of Interspecific Hybrid Rootstocks on Tomato Growth, Nutrient Accumulation, Yield, and Fruit Composition under Greenhouse Conditions}

\author{
Desire Djidonou, Xin Zhao ${ }^{1}$, Jeffrey K. Brecht, \\ and Kim M. Cordasco
}

ADDITIONAL INDEX wORDs. Solanum lycopersicum, Solanum lycopersicum $\times$ Solanum babrochaites, biomass, fruit quality, grafting, leaf area

Summary. Grafting is considered to be a unique component in sustainable vegetable production. In addition to its usefulness for managing soil-borne diseases, it has been suggested that grafting with vigorous rootstocks can improve crop growth and yield. The objective of this greenhouse study was to assess the effects of different interspecific hybrid tomato rootstocks (Solanum lycopersicum $\times$ Solanum habrochaites) on yield, growth, nutrient accumulation, and fruit composition of tomato (S. lycopersicum). Using the determinate tomato cultivar Florida 47 as the scion, plants were grafted onto four interspecific rootstock cultivars including Beaufort, Maxifort, Multifort, and RST-04-105. Overall, the use of rootstocks resulted in total and marketable fruit increase $53 \%$ and $66 \%$ higher than non-grafted and selfgrafted scion plants, respectively. The increase in marketable yield by 'Beaufort', 'Maxifort', and 'Multifort' was largely attributed to an increased number of fruit per plant, whereas higher average fruit weight contributed to the yield increase in plants grafted onto 'RST-04-105'. Self-grafting of 'Florida 47' resulted in similar yield as the non-grafted scion control. Analyses of plant growth parameters demonstrated significant enhancement of total leaf area at first fruit harvest in plants grafted onto interspecific rootstocks as compared with the non-grafted and selfgrafted scion controls. In addition to plant growth and yield improvement, enhanced accumulation of nitrogen, potassium, and calcium was also observed in grafted plants. The enhancement in mineral nutrient accumulation was largely related to increased biomass accumulation rather than higher nutrient concentration (on a dry weight basis). The overall accumulation of phosphorus was not influenced markedly by the rootstocks used. In general, grafting with the interspecific rootstocks maintained fruit soluble solids content (SSC) and total titratable acidity (TTA), concentrations of vitamin C, carotenoids, and total phenolics at levels comparable with non-grafted plants, whereas harvest date showed a more pronounced effect on fruit composition.

G rafting creates a new plant with combined desirable aboveground and belowground attributes from selected scion and rootstock plants. As an effective tool for management of root-knot nematodes (Meloidogyne spp.) and other soil-borne diseases (Guan et al., 2012; Louws et al., 2010), grafting has been successfully used in production of solanaceous

Horticultural Sciences Department, University of Florida, Gainesville, FL 32611

This work was supported by the University of Florida Institute of Food and Agricultural Sciences Research Innovation Funds.

Thanks are extended to Glenn Zalmann, Kaylene Sattano, and Elena Lon Kan for assisting with sample analyses. We are grateful to Karen E. Koch, Eric H. Simonne, and John E. Erickson for their comments on this manuscript.

${ }^{1}$ Corresponding author. E-mail: zxin@ufl.edu.

doi: 10.21273/HORTTECH03810-17 and cucurbitaceous vegetables such as tomato, eggplant (Solanum melongena), pepper (Capsicum annuum), watermelon (Citrullus lanatus), melon (Cucumis melo), and cucumber (Cucumis sativus) in both protected and openfield production systems (Lee and Oda, 2003; Lee et al., 2010). Beyond disease resistance, efficiency of nutrient and water use may increase in grafted vegetable plants, an effect often ascribed to the vigorous root systems of rootstocks (Albacete et al., 2015; Djidonou et al., 2013). Modification of endogenous plant hormone (e.g., cytokinins) status by the rootstock is also suggested to play an important role in promoting growth of grafted plants (Haroldsen et al., 2012; Lee et al., 2010).

The performance of grafted vegetables may vary substantially among rootstock-scion combinations. It was reported that potential for yield increase in grafted melon was greatly dependent on the rootstock genotypes (Ruiz et al., 1997). Both tomato hybrid and interspecific tomato hybrid rootstocks are typically used for tomato production (King et al., 2010). Grafted tomato plants with interspecific hybrid rootstocks exhibit more vigorous growth and higher yield compared with self-rooted tomato scion plants and those grafted onto intraspecific rootstocks (Djidonou et al., 2013; Leonardi and Giuffrida, 2006; Schwarz et al., 2013). Interspecific rootstocks, including 'Maxifort' and 'Beaufort' are among the most popular tomato rootstocks in North America (King et al., 2010). In addition to resistance to a range of soilborne pathogens, they are recognized by both greenhouse and field growers (Kubota et al., 2008; Rivard et al., 2010) for improving plant vigor and yield of grafted tomato even under low disease pressure.

Considering the increasing interest among tomato growers in the use of grafting techniques for sustainable production (King et al., 2010; Rivard et al., 2010), more research is needed to elucidate the influence of available tomato rootstocks on plant growth, yield, and nutrient uptake beyond disease resistance. Fruit quality

\begin{tabular}{llll}
\hline $\begin{array}{l}\text { Units } \\
\begin{array}{l}\text { To convert U.S. to SI, } \\
\text { multiply by }\end{array}\end{array}$ & U.S. unit & SI unit & $\begin{array}{l}\text { To convert SI to U.S., } \\
\text { multiply by }\end{array}$ \\
\hline 29.5735 & $\mathrm{fl} \mathrm{oz}$ & $\mathrm{mL}$ & 0.0338 \\
25.4 & inch(es) & $\mathrm{mm}$ & 0.0394 \\
6.4516 & inch & $\mathrm{cm}^{2}$ & 0.1550 \\
0.4536 & $\mathrm{lb}$ & $\mathrm{kg}$ & 2.2046 \\
28.3495 & $\mathrm{oz}$ & $\mathrm{g}$ & 0.0353 \\
62.5000 & $\mathrm{oz} / \mathrm{lb}$ & $\mathrm{g} \cdot \mathrm{kg}^{-1}$ & 0.0160 \\
0.1 & $\mathrm{ppm}$ & $\mathrm{mg} / 100 \mathrm{~g}$ & 10 \\
0.1 & $\mathrm{ppm}$ & $\mathrm{mg} / 100 \mathrm{~mL}$ & 10 \\
1 & $\mathrm{ppm}$ & $\mu \mathrm{g} \cdot \mathrm{g}^{-1}$ & 1 \\
$\left({ }^{\circ} \mathrm{F}-32\right) \div 1.8$ & ${ }^{\circ} \mathrm{F}$ & ${ }^{\circ} \mathrm{C}$ & $\left({ }^{\circ} \mathrm{C} \times 1.8\right)+32$
\end{tabular}


assessment of grafted vegetables is also critical, especially because some of the fruit quality attributes may be influenced by the physiological changes in grafted plants owing to rootstock-scion interactions (Flores et al., 2010; Rouphael et al., 2010). Increased levels of lycopene and $\beta$-carotene were observed in 'Fanny' and 'Goldmar' tomato fruit as a result of grafting with the 'AR-9704' rootstock under greenhouse conditions (Fernández-García et al., 2004), whereas a consistent decline in vitamin $\mathrm{C}$ content was detected in 'Cuore di Bue' tomato fruit when plants were grafted onto 'Beaufort' or 'Maxifort' rootstock (Di Gioia et al., 2010). Although research is increasing, especially in the United States to explore effects of the hybrid tomato rootstocks on soilborne disease control and yield increase (Barrett et al., 2012; McAvoy et al., 2012; Rivard et al., 2010), less is known about the underlying effects of vigorous rootstocks on plant growth, nutrient uptake, and fruit quality.

The objectives of this greenhouse pot study were to 1) determine the biomass, nutrient accumulation, and yield performance of tomato plants grafted onto disease-resistant interspecific hybrid rootstocks under greenhouse conditions without soilborne disease pressure and 2) assess the effects of different rootstocks on quality attributes of tomato fruit.

\section{Materials and methods}

TOMATO GRAFTING AND PLANTING. This study was conducted from January to June 2009 in a research greenhouse located on the University of Florida campus (Gainesville). Four commercially available interspecific tomato hybrid rootstocks including 'Beaufort', 'Maxifort', 'Multifort' (De Ruiter Seeds, Bergschenhoek, The Netherlands), and 'RST-04-105' (DP Seeds, Yuma, AZ) were assessed. A commonly grown determinate field tomato cultivar, Florida 47 (Seminis Vegetable Seeds, St. Louis, MO) was used as the scion. Seeds of the four rootstocks were sown on 2 Jan. 2009, and seeds of 'Florida 47' were sown on 6 Jan. 2009 into 128-cell Styrofoam flats (Speedling, Sun City, FL) using growing media (Metro-Mix 200;
Sun Gro Horticulture, Bellevue, WA) inside the greenhouse.

Plants were grafted using the splice method (Lee, 1994) on 29 Jan. 2009 when five to six true leaves were present. Grafted plants were placed in a closed healing chamber equipped with two humidifiers to maintain the relative humidity $(\mathrm{RH})$ above $80 \%$ and with an autocontrol air conditioning system for healing the grafts, where temperature was maintained at $25 \pm 3{ }^{\circ} \mathrm{C}$. The healing chamber was kept closed for the first $3 \mathrm{~d}$ to keep the grafted plants under dark conditions and then plants were gradually exposed to light by increasing the opening of the chamber until grafts were completed healed. Twelve days after grafting, control plants, including non-grafted 'Florida 47' (FL) and self-grafted 'Florida 47' (FL/ FL), as well as completely healed grafted plants from 'Florida 47'/'Beaufort' (FL/BE), 'Florida 47' /'Maxifort' (FL/ MA), 'Florida 47'/'Multifort' (FL/ MU), and 'Florida 47'/'RST-04-105' (FL/RS) were transplanted into three-gal black plastic pots filled with horticultural grade perlite. A randomized complete block design with four replications was used, with six plants in each treatment per replication.

A fertigation system using injectors (Dosatron International, Clearwater, FL) and $0.50 \mathrm{gal} / \mathrm{h}$ drippers (Netafim, Fresno, CA) was set up to deliver nutrient solution to each plant. Nutrient solution formulations developed by Hochmuth and Hochmuth (2001) for commercial greenhouse tomato production were modified to provide solutions containing concentrated macro and micro nutrients as follows: $236 \mathrm{~mm}$ phosphoric acid $\left(\mathrm{H}_{3}\right.$ $\left.\mathrm{PO}_{4}\right), 321 \mathrm{~mm}$ potassium chloride (KCl), $398 \mathrm{~mm}$ magnesium sulfate $\left(\mathrm{MgSO}_{4}\right), 237 \mathrm{~mm}$ potassium nitrate $\left(\mathrm{KNO}_{3}\right), \quad 550 \mu \mathrm{M}$ copper sulfate $\left(\mathrm{CuSO}_{4}\right), 2 \mathrm{mM}$ manganous sulfate $\left(\mathrm{MnSO}_{4}\right), 54 \mu \mathrm{M}$ zinc sulfate $\left(\mathrm{ZnSO}_{4}\right)$, $1 \mathrm{~mm}$ disodium octaborate $\left(\mathrm{Na}_{2} \mathrm{~B}_{8}\right.$ $\left.\mathrm{O}_{13}\right)$, and $100 \mathrm{~mm}$ sodium molybdate $\left(\mathrm{Na}_{2} \mathrm{MoO}_{4}\right)$ in stock $\mathrm{A} ; 1581 \mathrm{mM}$ calcium nitrate $\left(\mathrm{CaNO}_{3}\right)$ and $79 \mathrm{~mm}$ chelated iron ( $\mathrm{Fe} 330)$ in stock B. By adjusting dilution rates, mixed nutrient solutions of appropriate concentrations were supplied to plants based on plant growth and development (Hochmuth and Hochmuth, 2001). Twenty to 30 cycles were scheduled each day to fertigate each plant with a 1 - or 2-min delivery per cycle. Axial branches (suckers) below the first fruit cluster were pruned during this greenhouse experiment. The average air temperatures in the greenhouse during the pot study were $25 / 22^{\circ} \mathrm{C}$ (day/night), and the average RH was $64 \%$.

Plant growth AND NUTRIENT accumulation. One plant from each treatment per replication was sampled at 28,63 , and $120 \mathrm{~d}$ after transplanting [DAT (representing anthesis, first fruit harvest, and final fruit harvest, respectively)] for destructive analyses of plant total leaf area, aboveground biomass, and mineral nutrient accumulation. Each sampled plant was separated into leaf blades, petioles, stems, fruit, and roots. After measuring the fresh weight (FW) of each pooled fraction, representative subsamples $(\approx 300 \mathrm{~g}$ each with $500 \mathrm{~g}$ for fruit) were used to determine FW/ dry weight ratios. Dried weights were obtained by drying the subsamples in a forced-air oven at $60{ }^{\circ} \mathrm{C}$ for $72-$ $120 \mathrm{~h}$ to a constant weight. Data were used to calculate total plant dry weight and that of the component tissues. Leaf blade area of the subsamples was measured using a leaf area meter (LI 3100; LI-COR, Lincoln, NE). Total leaf area of the whole plant was then estimated accounting for the total FW of leaf blade.

Dried subsamples of each plant part (i.e., blade, petiole, stem, and fruit) were ground using a Wiley mill (A.H. Thomas Co., Philadelphia, PA) until particles could pass through a $1-\mathrm{mm}$ screen. To accurately assess the mineral nutrient status of each plant part, ground tissue samples from different parts of the plant were analyzed separately for the determination of concentrations of nitrogen $(\mathrm{N})$, phosphorus $(\mathrm{P})$, potassium $(\mathrm{K})$, and calcium (Ca) based on procedures described by Mylavarapu et al. (2004). Kjeldahl N was determined using automated colorimetric analysis. Inductively coupled plasma spectrophotometry was used to analyze $\mathrm{K}$ and $\mathrm{Ca}$ concentrations, whereas atomic absorption spectroscopy in combination with colorimetric analysis was used for $\mathrm{P}$ analysis. Accumulation of $\mathrm{N}, \mathrm{P}, \mathrm{K}$, and $\mathrm{Ca}$ into aboveground plant parts was estimated based on the dry weights of blade, petiole, stem, and fruit fractions and the collective nutrient levels in each of these plant parts. 
Tomato Yield MEASUREMENT. Tomato fruit were harvested at or after the breaker stage of ripeness. Fruit were harvested nine times from four plants in each treatment per replication between 63 and 120 DAT. These harvests were reported as yields from early, mid, and late harvest periods of the season, with each period representing three harvests at a 5- or 6-d interval. Total, marketable, and cull fruit yields were measured. Fruit were culled for blossom end rot (BER) symptoms, cracks, and catfacing. Yield components including average number of total and marketable fruit per plant and average single fruit weight were also reported.

FRUIT COMPOSITION ASSESSMENT. Quality attributes of tomato fruit were analyzed during the early (71 DAT) and mid (86 DAT) fruit harvest periods. Composite samples of five randomly selected, marketable, and ripe fruit from each treatment per replication were used for measurements of pH, TTA, SSC, vitamin C, lycopene, and $\beta$-carotene concentrations, and total phenolic content. To ensure similar ripeness of fruit across different treatments, tomato fruit were first stored at $20{ }^{\circ} \mathrm{C}$ after harvest and fruit color near the blossom end was monitored using a colorimeter (Minolta CR-400; Konica Minolta Sensing Americas, Ramsey, NJ). When the " $\mathrm{a}^{*}$ " value (negative for green and positive for red) reached the positive peak level followed by a plateau, fruit were considered to be full ripe and were cut into quarters and frozen at $-30{ }^{\circ} \mathrm{C}$ before extraction. Subsamples of the well-mixed frozen fruit samples were thawed and homogenized and then centrifuged $\left(20 \mathrm{~min}, 17,600 \mathrm{~g}_{\mathrm{n}}\right.$, $4{ }^{\circ} \mathrm{C}$ ). The resulting supernatant was filtered through cheesecloth before analysis of TTA, pH, and SSC. The TTA was determined by titration (719 $S$ Titrino; Metrohm USA, Riverview, FL) of $6.0 \mathrm{~g}$ of juice plus $50 \mathrm{~mL}$ of water with $0.1 \mathrm{~N}$ sodium hydroxide solution until $\mathrm{pH} 8.2$ was reached and the TTA was expressed as percent citric acid. The $\mathrm{pH}$ of the diluted juice was determined automatically using the same equipment for TTA determination. Soluble solids content was measured by a digital refractometer (model ABBE Mark II; Reichert Technologies, Depew, NY).

The concentration of vitamin $\mathrm{C}$ in the thawed and homogenized tomato fruit samples was measured spectrometrically according to the AOAC method 967.21 (AOAC International, 2000) and expressed as the total of ascorbic acid plus dehydroascorbic acid, comprising the total biologically active vitamin. The modified method of Nagata and Yamashita (1992) was used to determine concentrations of lycopene and $\beta$-carotene. Briefly, $1.0 \mathrm{~g}$ of homogenized fruit sample was mixed with $16 \mathrm{~mL}$ of acetone/hexane $(2: 3, \mathrm{v} / \mathrm{v})$ solvent. For carotenoid extraction, the mixture was placed in a freezer at $-20^{\circ} \mathrm{C}$ for $60 \mathrm{~min}$, followed by vortex shaking for $30 \mathrm{~s}$ (fast speed). Two phases were separated in the extract. An aliquot from the upper phase (the lower phase was discarded) was measured for absorbance (Abs) at 663, 645,505 , and $453 \mathrm{~nm}$ by spectrophotometer, using the hexane solvent as a blank. The final concentrations of lycopene and $\beta$-carotene in the fruit samples (micrograms per gram FW) were calculated based on the following equations (in $\mathrm{mg} / 100 \mathrm{~mL}$ of extract): lycopene $=-0.0458 \times$ Abs663 + $0.204 \times$ Abs $645+0.372 \times$ Abs505-0.0806 $\times$ Abs453; $\beta$-carotene $=$ $0.216 \times$ Abs663 - $1.22 \times$ Abs645 $0.304 \times$ Abs505 + $0.452 \times$ Abs 453 (Nagata and Yamashita, 1992). Phenolic contents in the hydrophilic and lipophilic fractions of the fruit extracts were determined as described previously by Toor and Savage (2005). Gallic acid was used as the standard and results were expressed as gallic acid equivalents per $100 \mathrm{~g} \mathrm{FW}$.

Statistical analyses. Analysis of variance was performed using the Proc Mixed procedure of SAS (version 9.2 for Windows; SAS Institute, Cary, NC). Data at each sampling were analyzed separately except for the fruit quality attributes, which were analyzed by adding the harvest date to the model as a fixed effect in addition to the grafting effect. Multiple comparisons among treatments were performed using Fisher's least significant difference test at $P \leq 0.05$.

\section{Results and discussion}

Plant growth. In this study, leaf area and total aboveground dry matter accumulation were similar between non-grafted 'Florida 47'and grafted plants with interspecific rootstocks at 28 DAT; i.e., the anthesis stage (Table 1 ). However, more vigorous growth as a result of grafting with interspecific rootstocks was observed as plant development progressed. At 63 DAT (i.e., first fruit harvest), grafting with all the interspecific rootstocks led to a significant increase in leaf area. Specifically, the average total leaf area of tomato plants grafted onto these rootstocks was $37 \%$ and $41 \%$ greater than that of non-grafted and self-grafted plants, respectively. In addition, total aboveground biomass of FL/MA and FL/ MU was significantly higher than FL/ FL and FL. Plant growth declined toward the final fruit harvest (120 DAT), whereas FL/MA appeared to retain growth vigor, exhibiting significantly higher aboveground biomass and larger leaf area at final harvest relative to FL and FL/FL. The root dry weight of grafted plants was significantly lower than that of nongrafted plants at 28 DAT. Grafting with interspecific rootstocks led to similar root dry weight compared with non-grafted plants at 63 and 120 DAT, whereas self-grafting resulted in a significant reduction of root dry weight throughout the growing season. It was possible that the grafting and healing process might have caused the decrease in root development in the selfgrafted plants without using the vigorous interspecific tomato hybrid rootstocks.

Although leaf area measurements were not taken between first and final harvests, it was possible that most grafted plants had increased leaf area in contrast to the non-grafted and self-grafted plants during the main fruit production period. The greater leaf area of grafted plants probably helped improve photosynthesis and accumulation of aboveground biomass, which in turn could lead to improved fruit yield. Previous studies have demonstrated improved growth of tomato, melon, and watermelon plants as a result of grafting with vigorous rootstocks under different production systems (Colla et al., 2010; Di Gioia et al., 2010; Leonardi and Giuffrida, 2006). Although the vigorous root system of rootstocks has been suggested to cause the enhanced aboveground growth (Lee et al., 2010), the root dry weight measured in this greenhouse pot study did not differ significantly 
between grafted and non-grafted tomato plants. The overall architecture of these roots was not assessed in this study, which may reveal potentially different traits (e.g., specific root length) between non-grafted plants and plants grafted with interspecific rootstocks.

CONCENTRATIONS AN D accumulation of $\mathbf{N}, \mathbf{P}, \mathbf{K}$, ANd $\mathbf{C A}$ IN ABOVEGROUND PLANT TISSUES. The concentrations of $\mathrm{N}, \mathrm{P}, \mathrm{K}$, and $\mathrm{Ca}$ in plant tissues varied considerably between treatments (Tables 2 and 3 ). At
28 DAT, FL/MA had significantly higher $\mathrm{N}$ and $\mathrm{Ca}$ concentrations in leaf blades than FL, whereas FL/BE, $\mathrm{FL} / \mathrm{MU}$, and FL/RS had higher concentrations of $\mathrm{K}$ than $\mathrm{FL}$ and FL/FL. By contrast, $P$ concentrations in leaf blades were consistently lower in grafted plants than non-grafted plants. Concentrations of $\mathrm{N}$ in the leaf petiole were similar among all the treatments, whereas self-grafted 'Florida 47' and 'Florida 47' grafted onto all interspecific rootstocks except FL/RS had significantly lower concentrations of $\mathrm{P}$ than non-grafted 'Florida 47'. Concentration of $\mathrm{K}$ in the leaf petiole was significantly higher in FL/RS, whereas Ca concentrations were significantly higher in FL/MA and FL/MU as compared with FL and FL/FL. Grafting did not significantly affect the concentrations of $\mathrm{K}$ and $\mathrm{Ca}$ in the stem. FL/MU had a significantly higher $\mathrm{N}$ concentration than FL. With respect to $\mathrm{P}$ in the stem, FL/BE and FL/MA had lower concentrations of $\mathrm{P}$ than FL. Overall, $\mathrm{N}$ concentrations were highest in the

Table 1. Leaf area and dry weight of plant tissues from non-grafted 'Florida 47' (FL) tomato plants, self-grafted 'Florida 47' (FL/FL) plants, and grafted 'Florida 47' plants with 'Beaufort' (FL/BE), 'Maxifort' (FL/MA), 'Multifort' (FL/MU), or 'RST-04-105' (FL/RS) rootstock.

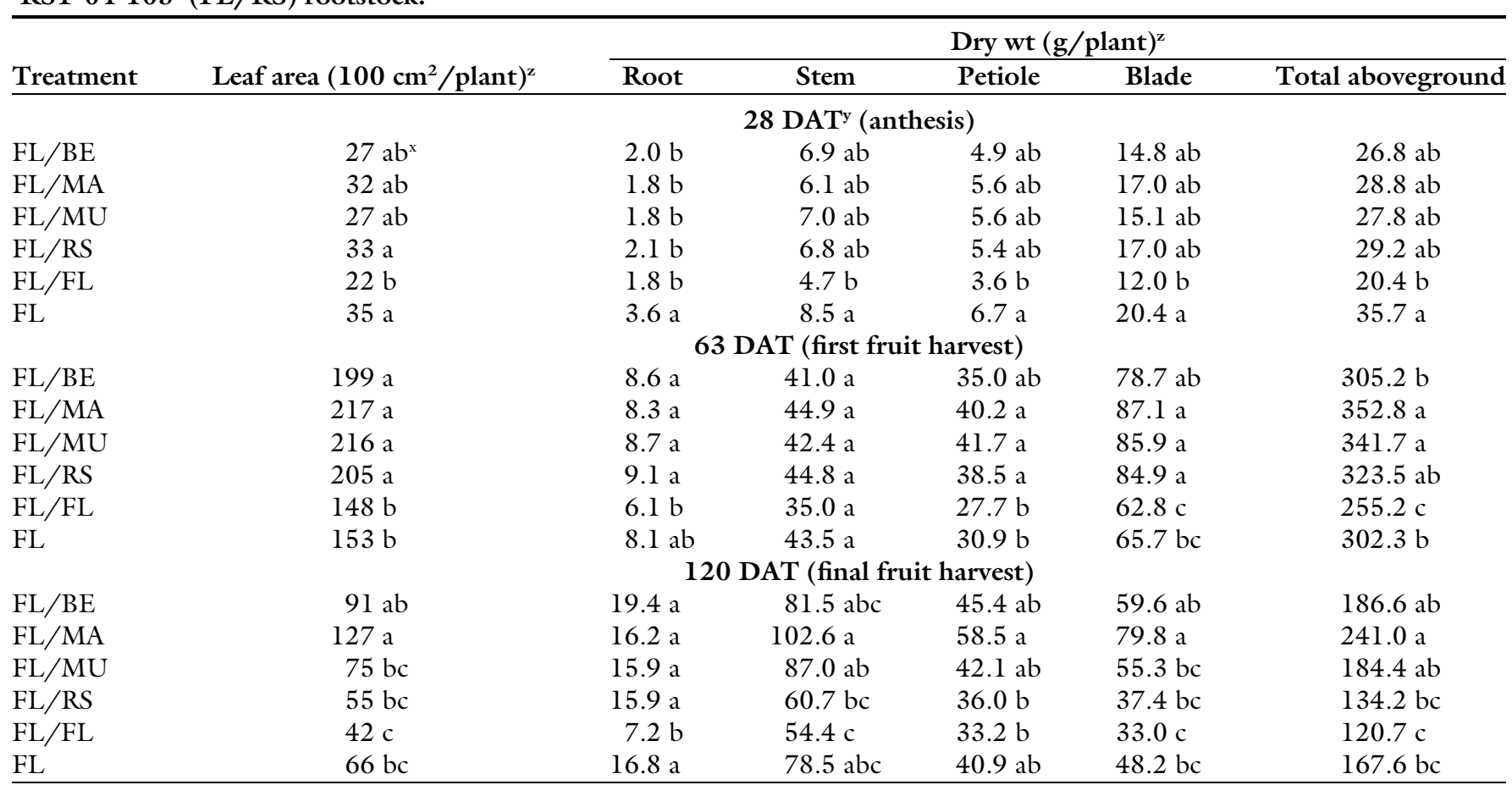

${ }^{\mathrm{z}} 1 \mathrm{~cm}^{2}=0.1550$ inch $^{2}, 1 \mathrm{~g}=0.0353 \mathrm{oz}$.

${ }^{\mathrm{y}}$ Days after transplanting.

${ }^{\mathrm{x}}$ Means within a column followed by the same letter are not significantly different at $P \leq 0.05$ according to Fisher's least significant difference test.

Table 2. Concentrations of nitrogen $(\mathrm{N})$, phosphorus $(\mathrm{P})$, potassium $(\mathrm{K})$, and calcium $(\mathrm{Ca})$ in aboveground tissues from non-grafted 'Florida 47' (FL) tomato plants, self-grafted 'Florida 47' (FL/FL) plants, and grafted 'Florida 47' plants with 'Beaufort' (FL/BE), 'Maxifort' (FL/MA), 'Multifort' (FL/MU), or 'RST-04-105' (FL/RS) rootstock at $28 \mathrm{~d}$ after transplanting.

\begin{tabular}{|c|c|c|c|c|c|c|c|c|c|c|c|c|}
\hline \multirow[b]{3}{*}{ Treatment } & \multicolumn{4}{|c|}{ Blade } & \multicolumn{4}{|c|}{ Petiole } & \multicolumn{4}{|c|}{ Stem } \\
\hline & $\mathbf{N}$ & $\mathbf{P}$ & $\mathbf{K}$ & $\mathrm{Ca}$ & $\mathbf{N}$ & $\mathbf{P}$ & $\mathbf{K}$ & $\mathrm{Ca}$ & $\mathbf{N}$ & $\mathbf{P}$ & $\mathbf{K}$ & $\mathrm{Ca}$ \\
\hline & \multicolumn{12}{|c|}{$\left(\mathrm{g} \cdot \mathrm{kg}^{-1} \mathrm{DW}\right)^{\mathrm{z}}$} \\
\hline $\mathrm{FL} / \mathrm{MA}$ & $60.7 \mathrm{a}$ & $8.45 \mathrm{~b}$ & $30.2 \mathrm{~b}$ & $32.1 \mathrm{a}$ & $33.0 \mathrm{a}$ & $7.8 \mathrm{c}$ & $70.1 \mathrm{ab}$ & $18.0 \mathrm{a}$ & $30.2 \mathrm{~b}$ & $8.6 \mathrm{~b}$ & $62.8 \mathrm{a}$ & $12.4 \mathrm{a}$ \\
\hline $\mathrm{FL} / \mathrm{MU}$ & $60.5 \mathrm{ab}$ & $8.5 \mathrm{~b}$ & $34.6 \mathrm{a}$ & $31.2 \mathrm{a}$ & $33.3 \mathrm{a}$ & $8.4 \mathrm{bc}$ & $69.9 \mathrm{ab}$ & $18.5 \mathrm{a}$ & $34.1 \mathrm{a}$ & $9.1 \mathrm{ab}$ & $55.4 \mathrm{a}$ & $12.3 \mathrm{a}$ \\
\hline $\mathrm{FL} / \mathrm{RS}$ & $58.1 \mathrm{ab}$ & $8.7 \mathrm{~b}$ & $34.7 \mathrm{a}$ & $27.6 \mathrm{~b}$ & $31.7 \mathrm{a}$ & $8.6 \mathrm{ab}$ & $72.0 \mathrm{a}$ & $17.1 \mathrm{ab}$ & $32.1 \mathrm{ab}$ & $8.9 \mathrm{ab}$ & $62.2 \mathrm{a}$ & $11.8 \mathrm{a}$ \\
\hline
\end{tabular}

${ }^{\mathrm{z}} 1 \mathrm{~g} \cdot \mathrm{kg}^{-1}=0.0160 \mathrm{oz} / \mathrm{lb}$. DW $=$ dry weight.

${ }^{\mathrm{y}}$ Means within a column followed by the same letter are not significantly different at $P \leq 0.05$ according to Fisher's least significant difference test. 


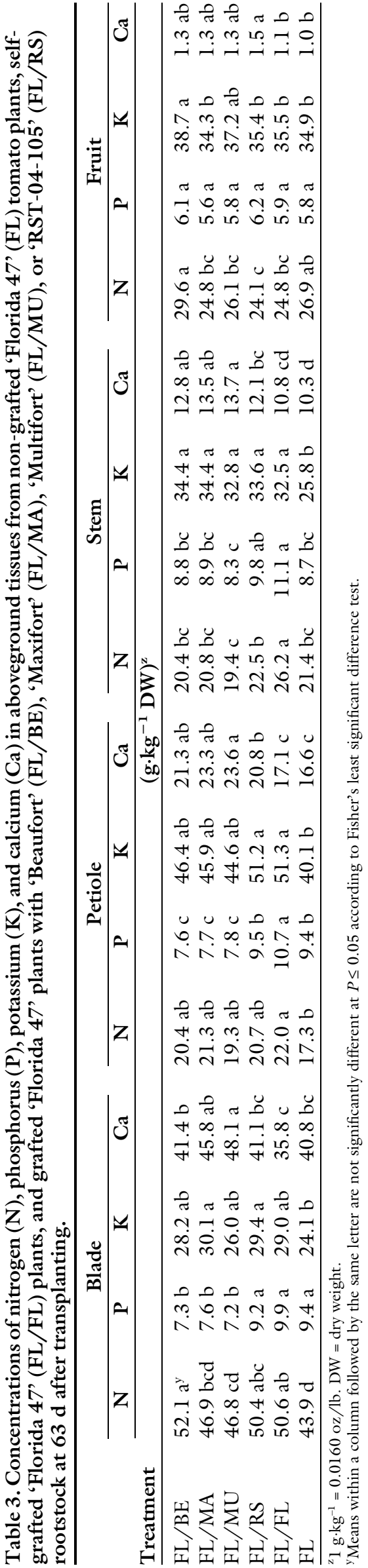

leaf blades despite the different grafting combinations, whereas $\mathrm{K}$ concentrations were highest in the petiole and stem.

Plant tissue mineral nutrient concentrations tended to decrease at 63 DAT relative to 28 DAT, especially for $\mathrm{N}$ and $\mathrm{K}$. Some differences in mineral nutrient concentrations were observed between grafted and non-grafted plants. FL/BE, $\mathrm{FL} / \mathrm{RS}$, and FL/FL had higher concentrations of $\mathrm{N}$ in the leaf blades than did FL, whereas FL/RS had a lower $\mathrm{N}$ concentration in the fruit (Table 3 ). Some grafting treatments with interspecific hybrid rootstocks also showed higher concentrations of $\mathrm{K}$ and $\mathrm{Ca}$ compared with nongrafted plants. For instance, K concentrations were significantly higher in the stem of all grafted vs. nongrafted plants, and in the FL/MA and $\mathrm{FL} / \mathrm{RS}$ plants, $\mathrm{K}$ levels were also higher in leaf blades. Similarly, plants grafted onto the interspecific rootstocks had significantly higher concentrations of $\mathrm{Ca}$ in their petioles and stems compared with nongrafted 'Florida 47'. FL/MU also had a higher $\mathrm{Ca}$ concentration in leaf blades compared with FL. The concentration of $\mathrm{P}$ in leaf blades and petioles was also significantly lower in the interspecific grafted plants except for FL/RS. At 120 DAT, few detectable differences remained in nutrient concentrations between grafted and non-grafted plants (data not shown).

In general, accumulation of $\mathrm{N}$, $\mathrm{K}$, and $\mathrm{Ca}$ in the aboveground tissues showed no significant difference between non-grafted plants and plants grafted with interspecific rootstocks at 28 DAT. However, accumulated $\mathrm{P}$ in some grafted plants, especially FL/BE, FL/MA, and $\mathrm{FL} / \mathrm{MU}$ were significantly lower than that in non-grafted plants (Table 4). At 63 DAT, enhanced mineral nutrient accumulation as a result of grafting with interspecific rootstocks was in accordance with vigorous growth of grafted plants relative to the control plants (Tables 1 and 4). More specifically at this growth stage (63 DAT), grafting plants onto interspecific rootstocks resulted in significantly higher accumulations of $\mathrm{N}$ in the aboveground tissues compared with non-grafted 'Florida 47', whereas $\mathrm{N}$ accumulation in self-grafted plants did not differ significantly from non-grafted plants. Similarly, total accumulated $\mathrm{K}$ and $\mathrm{Ca}$ in the aboveground shoot were also significantly higher with grafted plants relative to non-grafted and self-grafted plants. On average, the increases of accumulated nutrients in grafted plants relative to the control plants were $21 \%, 26 \%$, and $52 \%$ for $\mathrm{N}$, $\mathrm{K}$, and $\mathrm{Ca}$, respectively. With respect to the accumulation of $\mathrm{Ca}, \mathrm{FL} / \mathrm{MA}$, and FL/MU also showed a significantly higher level than in FL/BE and FL/RS. By contrast, $\mathrm{P}$ accumulation was similar between grafted and non-grafted plants except that it was higher in FL/RS, FL/MU, and FL/MA than the self-grafted $(\mathrm{FL} / \mathrm{FL})$. At the end of the production season, grafted plants with certain interspecific hybrid rootstocks maintained higher levels of $\mathrm{N}, \mathrm{K}$, and $\mathrm{Ca}$ accumulation than FL/FL and FL, whereas little influence of rootstocks on the accumulation of $\mathrm{P}$ was observed (data not shown).

Under the conditions of the present study, enhanced levels of accumulated mineral nutrients, especially $\mathrm{N}, \mathrm{K}$, and Ca were observed in the grafted plants relative to those of non-grafted plants. Such differences in aboveground tissue nutrient accumulation might be determined primarily by the differences in accumulated biomass rather than the nutrient concentrations in plant tissues. Significant differences were also observed among rootstocks with regard to accumulations of $\mathrm{K}$ and $\mathrm{Ca}$. Leonardi and Giuffrida (2006) observed an increase of $31 \%$ to $115 \%$ in accumulated $\mathrm{N}, \mathrm{P}, \mathrm{K}, \mathrm{Ca}$, magnesium $(\mathrm{Mg})$, and sulfur (S) (kilograms per hectare) with tomato plants grafted on 'Beaufort' compared with self-grafted plants under greenhouse conditions. Furthermore, when watermelon was grafted onto two different rootstocks, Huang et al. (2016) found that the total uptake (milligrams per plant) and concentration (milligrams per gram $\mathrm{DW}$ ) of $\mathrm{N}, \mathrm{K}, \mathrm{Ca}, \mathrm{Fe}, \mathrm{Mg}$, and manganese $(\mathrm{Mn})$ in root, stem, leaf, fruit rind, and flesh were greater in grafted plants relative to non-grafted plants, most noticeably for $\mathrm{N}$ in grafted plants with 'Qingyanzhen 1' hybrid pumpkin rootstock (Cucurbita maxima $\times$ Cucurbita moschata) grown in a plastic greenhouse. This enhancement in 
Table 4. Total accumulation of nitrogen $(N)$, phosphorus $(P)$, potassium $(K)$, and calcium $(\mathrm{Ca})$ in aboveground tissues from non-grafted 'Florida 47' (FL) tomato plants, self-grafted 'Florida 47' (FL/FL) plants, and grafted 'Florida 47' plants with 'Beaufort' (FL/BE), 'Maxifort' (FL/MA), 'Multifort' (FL/MU), or 'RST-04-105' (FL/RS) rootstock at 28 and $63 \mathrm{~d}$ after transplanting (DAT).

\begin{tabular}{lcccc}
\hline & \multicolumn{4}{c}{ Accumulated nutrient $(\mathbf{g} / \mathbf{p l a n t})^{\mathbf{z}}$} \\
\cline { 2 - 5 } Treatment & $\mathbf{N}$ & $\mathbf{P}$ & $\mathbf{K}$ & $\mathbf{C a}$ \\
\hline FL/BE & $1.26 \mathrm{ab}^{\mathrm{y}}$ & $0.22 \mathrm{~b}$ & $1.28 \mathrm{ab}$ & $0.59 \mathrm{a}$ \\
$\mathrm{FL} / \mathrm{MA}$ & $1.40 \mathrm{ab}$ & $0.24 \mathrm{~b}$ & $1.29 \mathrm{ab}$ & $0.73 \mathrm{a}$ \\
FL/MU & $1.35 \mathrm{ab}$ & $0.24 \mathrm{~b}$ & $1.30 \mathrm{ab}$ & $0.65 \mathrm{a}$ \\
FL/RS & $1.38 \mathrm{ab}$ & $0.26 \mathrm{ab}$ & $1.40 \mathrm{ab}$ & $0.64 \mathrm{a}$ \\
FL/FL & $0.96 \mathrm{~b}$ & $0.20 \mathrm{~b}$ & $0.95 \mathrm{~b}$ & $0.53 \mathrm{a}$ \\
FL & $1.60 \mathrm{a}$ & $0.34 \mathrm{a}$ & $1.53 \mathrm{a}$ & $0.77 \mathrm{a}$ \\
& & $63 \mathrm{DAT}$ & & $4.71 \mathrm{~b}$ \\
FL/BE & $9.91 \mathrm{a}$ & $2.06 \mathrm{bc}$ & $10.73 \mathrm{~b}$ & $5.70 \mathrm{a}$ \\
FL/MA & $10.02 \mathrm{a}$ & $2.35 \mathrm{ab}$ & $11.93 \mathrm{a}$ & $5.89 \mathrm{a}$ \\
FL/MU & $9.91 \mathrm{a}$ & $2.23 \mathrm{ab}$ & $11.51 \mathrm{ab}$ & $5.01 \mathrm{~b}$ \\
FL/RS & $9.62 \mathrm{a}$ & $2.49 \mathrm{a}$ & $11.10 \mathrm{ab}$ & $3.21 \mathrm{~d}$ \\
FL/FL & $7.82 \mathrm{~b}$ & $2.02 \mathrm{c}$ & $8.72 \mathrm{c}$ & $3.80 \mathrm{c}$ \\
FL & $8.42 \mathrm{~b}$ & $2.18 \mathrm{ab}$ & $9.27 \mathrm{c}$ &
\end{tabular}

${ }^{\mathrm{z}} 1 \mathrm{~g}=0.0353 \mathrm{oz}$.

${ }^{\mathrm{y}}$ Means within a column followed by the same letter are not significantly different at $P \leq 0.05$ according to Fisher's least significant difference test.

accumulated nutrients may actually be directly linked to the increased growth and development by grafted plants (Lee, 1994; Lee et al., 2010). In fact, in our study, grafting with vigorous rootstocks did not consistently result in increased mineral nutrient concentrations in different plant tissues. In contrast to some of the previous studies, the leaf concentrations of $\mathrm{P}$ in this study tended to be lower in grafted plants, especially with 'Maxifort', 'Multifort', and 'Beaufort' rootstocks, relative to non-grafted 'Florida 47'. Furthermore, it is also suggested that the positive influence of rootstocks on the nutrient contents of the aboveground plant tissues may depend on the physical characteristics of the root system, such as lateral and vertical development (Lee, 1994; MartínezBallesta et al., 2010).

In addition to enhanced nutrient uptake, other underlying physiological and molecular modifications responsible for improved growth and fruit yield of grafted vegetables have been studied. For instance, higher nitrate reductase activity was found in leaf tissues of grafted melon (Ruiz and Romero, 1999) and watermelon (Pulgar et al., 2000) plants in contrast to non-grafted plants. Hormonal signaling involved in rootstock-scion interactions (e.g., cytokinins) may also play an important role in growth and yield enhancement of grafted vegetables (Aloni et al., 2010; Lee and Oda, 2003). Moreover, longdistance translocation of mRNAs through phloem from rootstocks to scions was demonstrated in grafted 'INT 7B RS' pumpkin (C. maxima) plants with the 'Noy Israel' melon rootstock (Omid et al., 2007). Although most research was conducted on grafted cucurbits, future studies are warranted to elucidate how rootstockscion hormonal communications influence growth and development of grafted tomato and other solanaceous vegetable plants.

TOMATO Yield COMPONENTS. During the early harvest period (from 63 to 78 DAT), total yields were similar between grafted and nongrafted treatments. However, the marketable yields of grafted plants with interspecific rootstocks were significantly higher than those of nongrafted and self-grafted 'Florida-47', which was mainly due to the reduction in cull fruit yield (Table 5). Compared with non-grafted plants, FL/MA, FL/RS, and FL/BE showed significantly lower cull fruit yields. By contrast, self-grafting of 'Florida-47' resulted in a significant decrease in total and cull fruit yields compared with non-grafted plants. At the mid harvest, grafted plants with interspecific rootstocks demonstrated significantly higher total and marketable yields relative to those of the control plants, whereas cull fruit weight did not differ significantly between grafted and non-grafted plants. During the late harvest, grafting with interspecific rootstocks led to a significant increase in both total yield and cull fruit weight. The marketable yield was much lower in comparison with early and mid harvests as most of the harvested fruit developed BER irrespective of the treatments.

On average, grafted plants showed an increase in full-season total and marketable yields of $53 \%$ and $66 \%$, respectively, relative to the averaged yields of non-grafted and self-grafted plants (Table 5). The four rootstocks tested resulted in similar total and marketable fruit yields. With respect to total fruit yield per plant, grafting with interspecific rootstocks significantly increased average fruit weight during the three harvest periods, whereas it did not affect the fruit number per plant except that FL/ MU and FL/RS showed higher number of fruit than FL during the late harvest. At the mid harvest, which accounted for $47 \%$ to $56 \%$ of the total marketable yield, grafted plants with interspecific rootstocks demonstrated a significant increase in both fruit number (except for FL/RS) and average fruit weight compared with non-grafted and selfgrafted plants. Calculation of the fullseason marketable yield revealed a more pronounced effect of grafting on increasing marketable fruit number than average fruit weight. Grafted plants with interspecific rootstocks except for FL/RS had significantly higher numbers of fruit than FL, whereas FL/RS showed greater average fruit weight than FL.

Overall, the tomato yield improvement by grafting with interspecific rootstocks observed in this study is consistent with previous reports of grafted tomato production in other regions. Leonardi and Giuffrida (2006) found a 36\% higher marketable yield in grafted tomato plants with 'Beaufort' rootstock vs. selfgrafted plants. Pogonyi et al. (2005) also noted an increase of $\approx 62 \%$ in tomato yield by grafting tomato cultivar Lemance Fl onto Beaufort rootstock. In the present study, the enhancement in marketable yield by these interspecific rootstocks was primarily due to the increase of fruit 
Table 5. Total and marketable yields, number of fruit, and average fruit weight of tomatoes from non-grafted 'Florida 47' (FL) plants, self-grafted 'Florida 47' (FL/FL) plants, and grafted 'Florida 47' plants with 'Beaufort' (FL/BE), 'Maxifort' (FL/MA), 'Multifort' (FL/MU), or 'RST-04-105' (FL/RS) rootstock.

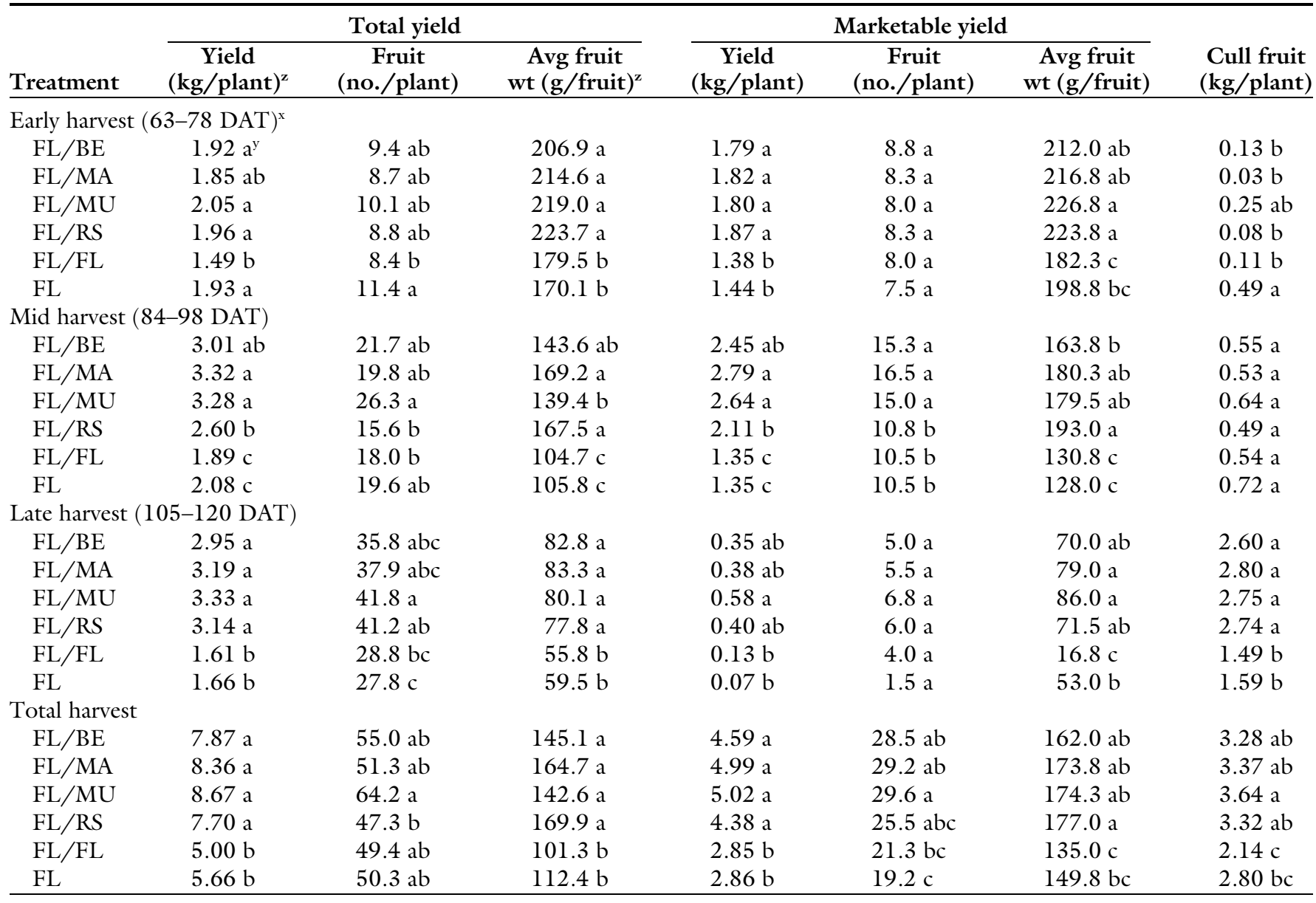

${ }^{\mathrm{z}} 1 \mathrm{~g}=0.0353 \mathrm{oz}, 1 \mathrm{~kg}=2.2046 \mathrm{lb}$.

'Means within a column followed by the same letter are not significantly different at $P \leq 0.05$ according to Fisher's least significant difference test.

${ }^{x}$ Days after transplanting.

number per plant or increased average fruit weight depending on the specific rootstocks used. This is in line with other studies that showed positive rootstock-scion interactions on the yield components of grafted tomatoes (Leonardi and Giuffrida, 2006; Pogonyi et al., 2005). By contrast, Di Gioia et al. (2010) in a greenhouse trial did not observe a significant change in yield components as a result of grafting, although enhancement in fruit yields was reported. Furthermore, use of both non-grafted and self-grafted controls in this study showed that yield improvement in grafted plants could be ascribed to the specific rootstocks used rather than the grafting process per se.

Cull fruit showed a marked increase during the late harvest (Table 5 ), which was primarily due to severe incidence of BER regardless of the grafting treatment. Although the cause of BER is rather complex, its incidence is often linked to a local
Ca deficiency in the distal fruit tissue (Adams and Ho, 1993; Saure, 2001). As Ca was supplied to the plants at a sufficient level in this greenhouse study, it was likely that high temperatures inside the greenhouse during the late production season $\left(32{ }^{\circ} \mathrm{C}\right.$ on average during the late season when BER was prominent) largely contributed to the high incidence of BER. Previous research has shown that elevated canopy transpiration rates at high temperatures in plants with large leaf areas can lead to an increase of Ca transport preferentially to leaves rather than the rapidly developing fruit, thus causing BER (Adams and Ho, 1993; Ho and White, 2005; Li et al., 2001). The intrinsic influence of rootstocks on BER severity and the underlying mechanism including plant water relations deserve further studies.

Fruit composition. In general, the use of interspecific hybrid rootstocks did not negatively affect quality attributes of fruit composition evaluated in this study. Averaged over the two harvests, values of $\mathrm{pH}$, SSC, TTA, SSC:TTA, and concentrations of lycopene, $\beta$-carotene, and lipophilic phenolics in tomato fruit were similar between non-grafted plants and plants grafted with interspecific rootstocks (Table 6). By contrast, harvest date exhibited a more pronounced effect on fruit quality. SSC, SSC:TTA, and levels of lycopene and lipophilic phenolics were significantly increased at mid harvest (86 DAT) compared with those at early harvest (71 DAT) by $\approx 23 \%, 26 \%$, $18 \%$, and $48 \%$, respectively. Vitamin C and hydrophilic phenolics were influenced by the significant interaction between grafting and harvest date (Table 7). Levels of vitamin $C$ and hydrophilic phenolics measured at 86 DAT were consistently higher than those at 71 $\mathrm{DAT}$ in $\mathrm{FL} / \mathrm{BE}, \mathrm{FL} / \mathrm{FL}$, and FL. At 86 DAT, FL/MU showed a significantly lower vitamin $\mathrm{C}$ content than 
FL, whereas the hydrophilic phenolic content of tomato fruit was decreased in FL/MA compared with FL.

In the present work, measurements of flavor-related attributes $(\mathrm{pH}$, SSC, and TTA) as well as nutritionally important and health-promoting antioxidants (ascorbic acid, lycopene, $\beta$-carotene, and phenolics) revealed more pronounced influence of harvest date than grafting with different rootstocks. Similar results have been reported by Di Gioia et al. (2010) in another greenhouse study of grafted tomato. This indicates that assessment of rootstock effects on fruit quality may need to include multiple harvests to identify possible effects of developmental factors, environmental factors, or both.

Previous studies have also yielded inconsistent findings on changes in fruit composition attributes as affected by grafting with specific rootstocks. Some quality attributes were improved by grafting with certain rootstocks (Davis et al., 2008; Fernández-García et al., 2004; Huang et al., 2015), whereas neutral or negative effects were also noted (Dorais et al., 2008; Rouphael et al., 2010). More specifically, Fernández-García et al. (2004) observed significantly higher levels of lycopene and $\beta$-carotene when tomato cultivars Fanny and Goldmar were grafted onto the rootstock 'AR-9704'. Responses were evident in tomato fruit under both non-saline and saline conditions depending on the scion cultivar. Although Pogonyi et al. (2005) reported lower SSC and TTA values in 'Lemance Fl' tomato fruit from plants grafted onto 'Beaufort', our study showed similar levels of these flavorrelated attributes over the two harvests. Di Gioia et al. (2010) detected a consistent decline in vitamin $\mathrm{C}$ content in 'Cuore di Bue' tomato fruit from grafted plants compared with non-grafted plants at various harvest dates while a significant harvest date by grafting interaction was observed in our study. Vinkovic Vrcek et al. (2011) observed a decrease in total phenolics as a result of grafting with three different commercial rootstocks including 'Efialto', 'Heman', and 'Maxifort'. Flores et al. (2010) speculated that in grafted plants, metabolic processes inherent to nutritional fruit quality may largely be species-driven and controlled by the scion. However, some of the fruit quality attributes may also be influenced by certain rootstocks as a result of long distance transport of metabolites, hormones, and RNAs moving to the scion through xylem or phloem (Lee, 1994; Rouphael et al., 2010). Furthermore, mixed results presented in the current literature could be more related to the fact that nutritional quality attributes of tomato fruit are highly affected by the genotype $\times$ environment interactions

Table 6. Quality attributes of fruit from non-grafted 'Florida 47' (FL) tomato plants, self-grafted 'Florida 47' (FL/FL) plants, and grafted 'Florida 47' plants with 'Beaufort' (FL/BE), 'Maxifort' (FL/MA), 'Multifort' (FL/MU), or 'RST-04105' (FL/RS) rootstock during early and mid fruit harvests.

\begin{tabular}{|c|c|c|c|c|c|c|c|}
\hline$\underline{\text { Treatment }}$ & $\mathrm{pH}$ & $\begin{array}{c}\text { TTA }^{\mathrm{z}} \\
(\% \text { citric acid }) \\
\end{array}$ & $\mathrm{SSC}^{\mathrm{z}}(\%)$ & $\begin{array}{l}\text { SSC:TTA } \\
\text { ratio }\end{array}$ & $\begin{array}{c}\text { Lycopene } \\
\left(\mu \mathrm{g} \cdot \mathrm{g}^{-1} \mathrm{FW}\right)^{\mathrm{y}}\end{array}$ & $\begin{array}{c}\beta \text {-carotene } \\
\left(\mu \mathrm{g} \cdot \mathrm{g}^{-1} \mathrm{FW}\right)\end{array}$ & $\begin{array}{c}\text { Lipophilic phenolics } \\
{[\mathrm{GAE}(\mathrm{mg} / 100 \mathrm{~g} \mathrm{FW})]^{\mathrm{x}}}\end{array}$ \\
\hline \multicolumn{8}{|l|}{ Harvest date } \\
\hline 86 DAT & $4.38 \mathrm{a}$ & $0.47 \mathrm{a}$ & $5.4 \mathrm{a}$ & $12.0 \mathrm{a}$ & $39.77 \mathrm{a}$ & $8.57 \mathrm{a}$ & $6.07 \mathrm{a}$ \\
\hline \multicolumn{8}{|l|}{ Grafting } \\
\hline $\mathrm{FL} / \mathrm{BE}$ & $4.44 \mathrm{a}$ & $0.45 \mathrm{a}$ & $4.9 \mathrm{a}$ & $11.0 \mathrm{a}$ & $38.20 \mathrm{a}$ & $9.22 \mathrm{ab}$ & $4.98 \mathrm{a}$ \\
\hline FL/RS & $4.39 \mathrm{a}$ & $0.47 \mathrm{a}$ & $4.8 \mathrm{a}$ & $10.6 \mathrm{a}$ & $35.34 \mathrm{a}$ & $8.55 \mathrm{ab}$ & $5.13 \mathrm{a}$ \\
\hline $\mathrm{FL} / \mathrm{FL}$ & $4.41 \mathrm{a}$ & $0.46 \mathrm{a}$ & $5.0 \mathrm{a}$ & $11.2 \mathrm{a}$ & $34.74 \mathrm{a}$ & $8.10 \mathrm{~b}$ & $5.36 \mathrm{a}$ \\
\hline FL & $4.40 \mathrm{a}$ & $0.51 \mathrm{a}$ & $5.2 \mathrm{a}$ & $10.3 \mathrm{a}$ & $37.40 \mathrm{a}$ & $8.97 \mathrm{ab}$ & $4.73 \mathrm{a}$ \\
\hline
\end{tabular}

${ }^{\mathrm{z}} \mathrm{TTA}=$ total titratable acidity, $\mathrm{SSC}=$ soluble solids content

${ }^{\mathrm{y}} 1 \mu \mathrm{g} \cdot \mathrm{g}^{-1}=1 \mathrm{ppm}$.

${ }^{x}$ Gallic acid equivalents; $1 \mathrm{mg} / 100 \mathrm{~g}=10 \mathrm{ppm}$. $\mathrm{FW}=$ fresh weight.

"Days after transplanting.

${ }^{\vee}$ Means within a column followed by the same letter are not significantly different at $P \leq 0.05$ according to Fisher's least significant difference test.

Table 7. Vitamin C and hydrophilic phenolic contents of fruit from non-grafted 'Florida 47' (FL) tomato plants, self-grafted 'Florida 47' (FL/FL) plants, and grafted 'Florida 47' plants with 'Beaufort' (FL/BE), 'Maxifort' (FL/MA), 'Multifort' (FL/MU), or 'RST-04-105' (FL/RS) rootstock during early and mid fruit harvests.

\begin{tabular}{|c|c|c|c|c|}
\hline \multirow[b]{2}{*}{ Treatment } & \multicolumn{2}{|c|}{ Vitamin C $[\mathrm{AA}(\mathrm{mg} / 100 \mathrm{~g} \mathrm{FW})]^{\mathrm{z}}$} & \multicolumn{2}{|c|}{ Hydrophilic phenolics [GAE (mg/100 g FW) $]^{\mathrm{z}}$} \\
\hline & $71 \mathrm{DAT}$ & 86 DAT & $71 \mathrm{DAT}$ & $86 \mathrm{DAT}$ \\
\hline $\mathrm{FL} / \mathrm{BE}$ & $16.53 \mathrm{Ab}^{\mathrm{y}}$ & $24.26 \mathrm{ABCa}$ & $10.83 \mathrm{Ab}$ & $17.09 \mathrm{Aa}$ \\
\hline $\mathrm{FL} / \mathrm{MU}$ & $15.53 \mathrm{Aa}$ & $16.64 \mathrm{Ca}$ & $11.20 \mathrm{Aa}$ & $16.06 \mathrm{ABa}$ \\
\hline $\mathrm{FL} / \mathrm{RS}$ & $15.30 \mathrm{Aa}$ & $22.70 \mathrm{BCa}$ & $11.90 \mathrm{Aa}$ & $18.17 \mathrm{Aa}$ \\
\hline $\mathrm{FL} / \mathrm{FL}$ & $16.87 \mathrm{Ab}$ & $30.71 \mathrm{Aa}$ & $10.85 \mathrm{Ab}$ & $17.32 \mathrm{Aa}$ \\
\hline
\end{tabular}

${ }^{\mathrm{z}} \mathrm{AA}=$ ascorbic acid, GAE = gallic acid equivalents, $\mathrm{FW}=$ fresh weight; $1 \mathrm{mg} / 100 \mathrm{~g}=10 \mathrm{ppm}$.

${ }^{\mathrm{y}}$ Means followed by the same uppercase letter within a column, and means followed by the same lowercase letter within a row are not significantly different at $P \leq 0.05$ according to Fisher's least significant difference test.

$\mathrm{DAT}=$ days after transplanting. 
(Panthee et al., 2012; Roselló et al., 2011) and cultural practices such as irrigation management, mineral nutrition, soil salinity, and growing system (soil vs. soilless medium) may also greatly influence tomato quality traits (Dorais et al., 2008).

\section{Conclusions}

Improved marketable fruit yields resulted from grafting with vigorous interspecific hybrid rootstocks in determinate tomato production under greenhouse conditions with sufficient water and nutrient supplies. Grafting showed a consistent effect on increasing average fruit weight for total fruit yield, although it tended to increase fruit number per plant for total marketable fruit yield. More research is warranted for understanding the influence of vigorous rootstocks on tomato BER incidence. Greater leaf area was also observed in grafted tomato plants compared with non-grafted and self-grafted scion plants. In general, grafted plants with interspecific rootstocks demonstrated greater accumulations of $\mathrm{N}, \mathrm{K}$, and Ca compared with non-grafted and self-grafted plants at first harvest. By contrast, the accumulation of $\mathrm{P}$ in aboveground tissues was similar between non-grafted plants and plants grafted onto different rootstocks. Results from this study suggested that tomato plants grafted with vigorous interspecific hybrid rootstocks may require different fertilization management for optimizing fruit yield in contrast to non-grafted plants. Overall, grafting with the interspecific hybrid rootstocks evaluated here did not consistently influence detectable attributes of fruit quality such as SSC, TTA, or levels of vitamin C, lycopene, carotenoid, and total phenolics. Harvest date exhibited a more pronounced effect on fruit composition than grafting. However, it is worth noting that most of those fruit quality factors were maintained on plants grafted with vigorous interspecific hybrid rootstocks even though average fruit weight and fruit number per plant were greater than for non-grafted plants.

\section{Literature cited}

Adams, P. and L.C. Ho. 1993. Effects of environment on the uptake and distribution of calcium in tomato and on the incidence of blossom-end rot. Plant Soil 154:127-132.
Albacete, A., C. Martínez-Andújar, A. Martínez-Pérez, A.J. Thompson, I.C. Dodd, and F. Pérez-Alfocea. 2015. Unravelling rootstock $\times$ scion interactions to improve food security. J. Expt. Bot. 66:2211-2226.

Aloni, B., R. Cohen, L. Karni, H. Aktas, and M. Edelstein. 2010. Hormonal signaling in rootstock-scion interactions. Sci. Hort. 127:119-126.

AOAC International. 2000. Ascorbic acid in vitamin preparations and juices 2,6dichloroindophenol titrimetric method, p. 887-891. In: W. Horowitz (ed.). Official methods of analysis. AOAC Intl., Gaithersburg, MD.

Barrett, C.E., X. Zhao, and R. McSorley. 2012. Grafting for root-knot nematode control and yield improvement in organic heirloom tomato production. HortScience 47:614-620.

Colla, G., C.M. Cardona Suárez, M. Cardarelli, and Y. Rouphael. 2010. Improving nitrogen use efficiency in melon by grafting. HortScience 45:559-565.

Davis, A.R., P. Perkins-Veazie, R. Hassell, A. Levi, S.R. King, and X. Zhang. 2008. Grafting effects on vegetable quality. HortScience 43:1670-1672.

Di Gioia, F., F. Serio, D. Buttaro, O. Ayala, and P. Santamaria. 2010. Influence of rootstock on vegetable growth, fruit yield and quality in 'Cuore di Bue', an heirloom tomato. J. Hort. Sci. Biotechnol. 85:477-482.

Djidonou, D., X. Zhao, E.H. Simonne, K.E. Koch, and J.E. Erickson. 2013. Yield, water-, and nitrogen-use efficiency in field-grown, grafted tomatoes. HortScience 48:485-492.

Dorais, M., D.L. Ehret, and A.P. Papadopoulos. 2008. Tomato (Solanum lycopersicum) health components: From the seed to the consumer. Phytochem. Rev. 7:231-250.

Fernández-García, N., V. Martínez, A. Cerdá, and M. Carvajal. 2004. Fruit quality of grafted tomato plants grown under saline conditions. J. Hort. Sci. Biotechnol. 79:995-1001.

Flores, F.B., P. Sanchez-Bel, M.T. Estañ, M.M. Martinez-Rodriguez, E. Moyano, B. Morales, J.F. Campos, J.O. GarciaAbellán, M.I. Egea, N. Fernández-Garcia, F. Romojaro, and M.C. Bolarín. 2010. The effectiveness of grafting to improve tomato fruit quality. Sci. Hort. 125:211217.

Guan, W., X. Zhao, R. Hassell, and J. Thies. 2012. Defense mechanisms involved in disease resistance of grafted vegetables. HortScience 47:164-170.
Haroldsen, V.M., M.W. Szczerba, H. Aktas, J. Lopez-Baltazar, M.J. Odias, C.L. Chi-Ham, J.M. Labavitch, A.B. Bennett, and A.L. Powell. 2012. Mobility of transgenic nucleic acids and proteins within grafted rootstocks for agricultural improvement. Front. Plant Sci. 3:39.

Ho, L.C. and P.J. White. 2005. A cellular hypothesis for the induction of blossomend rot in tomato fruit. Ann. Bot. 95:571-581.

Hochmuth, G.J. and R.C. Hochmuth. 2001. Nutrient solution formulation for hydroponic (perlite, rockwool, NFT) tomatoes in Florida. Univ. Florida. Coop. Ext. Serv. HS796. 13 Dec. 2009. $<$ http://edis.ifas.ufl.edu/pdffiles/CV/ CV21600.pdf $>$.

Huang, W., S. Liao, H. Lv, A.B.M. Khaldun, and Y. Wang. 2015. Characterization of the growth and fruit quality of tomato grafted on a woody medicinal plant, Lycium chinense. Sci. Hort. 197:447453.

Huang, Y., L. Zhao, Q. Kong, F. Cheng, M. Niu, J. Xie, M.A. Nawaz, and Z. Bie. 2016. Comprehensive mineral nutrition analysis of watermelon grafted onto two different rootstocks. Hort. Plant J. 2:105-113.

King, S.R., A.R. Davis, X. Zhang, and K. Crosby. 2010. Genetics, breeding and selection of rootstocks for Solanaceae and Cucurbitaceae. Sci. Hort. 127:106-111.

Kubota, C., M.A. Mcclure, N. KokalisBurelle, M.G. Bausher, and E.N. Rosskopf. 2008. Vegetable grafting: History, use, and current technology status in North America. HortScience 43:1664-1669.

Lee, J.M. 1994. Cultivation of grafted vegetables. I. Current status, grafting methods, and benefits. HortScience 29:235-239.

Lee, J.M., C. Kubota, S.J. Tsao, Z. Bie, P.H. Echevarria, L. Morra, and M. Oda. 2010. Current status of vegetable grafting: Diffusion, grafting techniques, automation. Sci. Hort. 127:93-105.

Lee, J.M. and M. Oda. 2003. Grafting of herbaceous vegetable and ornamental crops. Hort. Rev. 28:61-124.

Leonardi, C. and F. Giuffrida. 2006. Variation of plant growth and macronutrient uptake in grafted tomatoes and eggplants on three different rootstocks. Eur. J. Hort. Sci. 71:97-101.

Li, Y.L., C. Stanghellini, and H. Challa. 2001. Effect of electrical conductivity and transpiration on production of greenhouse tomato (Lycopersicon esculentum L.). Sci. Hort. 88:11-29.

Louws, F.J., C.L. Rivard, and C. Kubota. 2010. Grafting fruiting vegetables to 
manage soilborne pathogens, foliar pathogens, arthropods and weeds. Sci. Hort. 127:127-146.

Martínez-Ballesta, M.C., C. Alcaraz-López, B. Muries, C. Mota-Cadenas, and M. Carvajal. 2010. Physiological aspects of rootstock-scion interactions. Sci. Hort. 127:112-118.

McAvoy, T., J.H. Freeman, S.L. Rideout, S.M. Olson, and M.L. Paret. 2012. Evaluation of grafting using hybrid rootstocks for management of bacterial wilt in field tomato production. HortScience 47:621625 .

Mylavarapu, R.S., W. d'Angelo, N. Wilkinson, and D. Moon. 2004. UF/ IFAS extension soil testing laboratory (ESTL) analytical procedures and training manual. Univ. Florida Coop. Ext. Serv. Circ. 1248. 13 Mar. 2010. <http://edis. ifas.ufl.edu/pdffiles/SS/SS31200.pdf>.

Nagata, M. and I. Yamashita. 1992. Simple method for simultaneous determination of chlorophyll and carotenoids in tomato fruit. Nippon Shokuhin Kogyo Gakkaishi 39:925-928.

Omid, A., T. Keilin, A. Glass, D. Leshkowitz, and S. Wolf. 2007. Characterization of phloem-sap transcription profile in melon plants. J. Expt. Bot. 58:3645-3656.

Panthee, D.R., C. Cao, S.J. Debenport, G.R. Rodríguez, J.A. Labate, L.D.
Robertson, A.P. Breksa, III., E. van der Knaap, and B.B. McSpadden Gardener. 2012. Magnitude of genotype $\times$ environment interactions affecting tomato fruit quality. HortScience 47:721-726.

Pogonyi, A., Z. Pék, L. Helyes, and A. Lugasi. 2005. Effect of grafting on the tomato's yield, quality and main fruit components in spring forcing. Acta Aliment. 34:453-462.

Pulgar, G., G. Villora, D.A. Moreno, and L. Romero. 2000. Improving the mineral nutrition in grafted watermelon plants: $\mathrm{Ni}^{-}$ trogen metabolism. Biol. Plant. 43:607609.

Rivard, C.L., S. O'Connell, M.M. Peet, and F.J. Louws. 2010. Grafting tomato with interspecific rootstock to manage diseases caused by Sclerotium rolfsii and southern root-knot nematode. Plant Dis. 94:1015-1021.

Roselló, S., A.M. Adalid, J. Cebolla-Cornejo, and F. Nuez. 2011. Evaluation of the genotype, environment and their interaction on carotenoid and ascorbic acid accumulation in tomato germplasm. J. Sci. Food Agr. 91:1014-1021.

Rouphael, Y., D. Schwarz, A. Krumbein, and G. Colla. 2010. Impact of grafting on product quality of fruit vegetables. Sci. Hort. 127:172-179.

Ruiz, J.M., A. Belakbir, I. López-Cantarero, and L. Romero. 1997. Leaf-macronutrient content and yield in grafted melon plants. A model to evaluate the influence of rootstock genotype. Sci. Hort. 71:227234.

Ruiz, J.M. and L. Romero. 1999. Nitrogen efficiency and metabolism in grafted melon plants. Sci. Hort. 81:113-123.

Saure, M.C. 2001. Blossom-end rot of tomato (Lycopersicon esculentum Mill.) A calcium- or a stress-related disorder? Sci. Hort. 90:193-208.

Schwarz, D., G.B. Öztekin, Y. Tüzel, B. Brückner, and A. Krumbein. 2013. Rootstocks can enhance tomato growth and quality characteristics at low potassium supply. Sci. Hort. 149:70-79.

Toor, R.K. and G.P. Savage. 2005. Antioxidant activity in different fractions of tomatoes. Food Res. Intl. 38:487-494.

Vinkovic Vrcek, I., V. Samobor, M. Bojic, M. Medic-Saric, M. Vukobratovic, R. Erhatic, D. Horvat, and Z. Matotan. 2011. The effect of grafting on the antioxidant properties of tomato (Solanum lycopersicum L.). Span. J. Agr. Res. 9:844851. 